\title{
Pengaruh Pemberian Alopurinol terhadap Tekanan Darah Pasien Gagal Jantung
}

\author{
${ }^{1}$ Ribka Wowor, ${ }^{2}$ Frans Wantania \\ ${ }^{1}$ Fakultas Ilmu Kesehatan Masyarakat Universitas Sam Ratulangi Manado \\ ${ }^{2}$ Bagian/SMF Ilmu Penyakit Dalam Divisi Kardiologi Fakultas Kedokteran Universitas Sam \\ Ratulangi/RSUP Prof. Dr. R. D. Kandou, Manado \\ Email: ribkaladywowor@gmail.com
}

\begin{abstract}
Hyperuricemia is an independent risk factor of hypertension. Most of heart failure patients with uncontrolled hypertension had hyperuricemia. This study was aimed to determine the effect of allopurinol to blood pressure in heart failure patients. This was a clinical trial study with a control-non randomized design, performed on heart failure patients (40-74 years old). Wilcoxon Sign Rank was used to test the means of blood pressure difference between after and before the allopurinol treatment. The results showed that there were no significant differences in mean blood pressure between before and after allopurinol treatment (SBP, $P=0.650$; DBP, $P=0.356$ ). Conclusion: There was a decrease of blood pressure in heart failure patients after allopurinol treatment; albeit, it was not statistically significan.
\end{abstract}

Keywords: allopurinol, blood pressure, heart failure

\begin{abstract}
Abstrak: Hiperurisemia merupakan salah satu faktor risiko independen terhadap timbulnya hipertensi. Pasien gagal jantung dengan tekanan darah tidak terkontrol sering mengalami hiperurisemia. Penelitian ini bertujuan untuk mengetahui pengaruh pemberian alopurinol terhadap tekanan darah pada pasien gagal jantung. Penelitian ini merupakan uji klinis terbuka tanpa randomisasi untuk meneliti pengaruh pemberian alopurinol pada terapi standar congestive heart failure (CHF). Beda rerata tekanan darah pre dan post diuji menggunakan Wilcoxon Sign Rank. Hasil penelitian menunjukkan pada kelompok alopurinol didapatkan penurunan tekanan darah sesudah pemberian alopurinol walaupun perbedaan rerata pre-post TDS $(P=0,650)$ dan perbedaan rerata pre-post TDD tidak bermakna $(P=0,356)$. Simpulan: Pasien CHF yang diberikan alopurinol mengalami penurunan tekanan darah walaupun secara statistik tidak bermakna
\end{abstract}

Kata kunci: alopurinol, tekanan darah, gagal jantung

Hiperurisemia sering dikaitkan dengan kejadian hipertensi. ${ }^{1}$ Asam urat merupakan produk dari metabolisme purin dalam darah oleh xanthin oxidase, baik berasal dari purin endogen maupun berasal dari makanan. Alkohol, diet tinggi purin, kurangnya asupan cairan, dan kurangnya berolahraga merupakan beberapa penyebab terjadinya hiperurisemia. ${ }^{2}$ Peningkatan asam urat serum merupakan salah satu faktor risiko independen terhadap timbulnya hipertensi. Mekanisme dapat melalui beberapa cara seperti reaksi inflamasi, proliferasi sel otot polos vaskuler dalam mikrosirkulasi ginjal, disfungsi endotel, dan aktivasi sistem renin-angiotensinaldosteron. ${ }^{3}$ Sebaliknya, penurunan serum asam urat dikaitkan dengan kejadian penurunan tekanan darah melalui regulasi renin-angiotensin dan sistem nitrik oksida. ${ }^{1}$ Alopurinol bekerja menghambat aktivitas xanthin oxidase, yang kemudian akan menurunkan produk oksigen reaktif dan meningkatkan bioavailabilitas nitrik oksida, 
sehingga dapat meningkatkan fungsi dari endotel dan menurunkan tekanan darah. ${ }^{4}$

Berdasarkan hal ini, muncul hipotesis mengenai bagaimana efektifitas obat penurun asam urat serum terhadap pencegahan dan penanganan hipertensi. Tujuan penelitian ini ialah untuk mengetahui pengaruh pemberian allopurinol terhadap tekanan darah pada pasien dengan congestive heart failure (CHF).

\section{METODE PENELITIAN}

Penelitian ini merupakan uji klinis terbuka tanpa randomisasi, untuk meneliti pengaruh pemberian allopurinol pada terapi standar CHF, dilakukan di Poliklinik Jantung RSUP Prof. Dr. R. D. Kandou Manado selama 6 bulan, mulai bulan November 2015 sampai dengan April 2016.

Kriteria inklusi ialah pasien pria usia 40-80 tahun dengan CHF fungsional kelas II-III yang memenuhi kriteria Framingham, kadar asam urat $>7 \mathrm{mg} / \mathrm{d}$, dan bersedia ikut dalam penelitian serta menandatangani informed consent. Kriteria eksklusi ialah pasien dengan gout serangan akut, gangguan fungsi ginjal (penurunan eLFG < $30 \mathrm{ml} / \mathrm{menit}$ ), adanya riwayat pemakaian alopurinol sebelumnya, riwayat reaksi alergi terhadap alopurinol sebelumnya, serta riwayat asma dan tuberkulosis paru.

Pengambilan sampel dengan cara consecutive sampling. Besar sampel pada penelitian ini ditentukan berdasarkan rumus Kirk, dan diperoleh 17 orang/kelompok, dibulatkan menjadi 20 orang/kelompok.

Kriteria hipertensi didasarkan pada kriteria Joint National Committee (JNC) VIII tahun 2014 yaitu tekanan darah $\geq$ 140/90 mmHg. ${ }^{5}$ Kriteria hiperurisemia didasarkan pada kriteria Japanese guideline for the management of hyperuricemia and gout: Second edition, dimana hiperurisemia adalah konsentrasi asam urat darah $>7$ $\mathrm{mg} / \mathrm{dl}$ untuk pria dan $>6 \mathrm{mg} / \mathrm{dl}$ untuk wanita. $^{6}$

\section{HASIL PENELITIAN \\ Data karakteristik dasar subyek penelitian}

Penelitian dilakukan di Poliklinik
Jantung RSUP Prof. Dr. R. D. Kandou Manado selama 6 bulan, sejak bulan November 2015 sampai dengan April 2016, dan didapatkan 50 sampel semuanya lakilaki (100\%) yang memenuhi kriteria penelitian. Sebanyak 9 sampel dinyatakan drop out, karena tidak mengikuti prosedur penelitian dan 1 sampel meninggal dunia. Diperoleh 20 sampel perlakuan dan 20 sampel kontrol untuk dilakukan analisis data. Data diolah dengan program komputer SPSS versi 22.0.

Karakteristik sampel penelitian dapat dilihat pada Tabel 1. Pada kelompok alopurinol didapatkan usia termuda 40 tahun dan usia tertua 74 tahun. Rerata usia 60,90 tahun dengan simpang baku (SD) = 9,107 . Sampel usia 40-60 tahun sebanyak 8 orang (40\%) dan usia 61-80 tahun 12 orang (60\%). Pada kelompok kontrol didapatkan usia termuda 40 tahun dan usia tertua 76 tahun. Rerata usia 61,25 tahun dengan simpang baku $(\mathrm{SD})=8,058$. Sampel usia 40-60 tahun sebanyak 7 orang (35\%) dan usia 61-80 tahun 13 orang (65\%) (Tabel 2).

Dari 40 orang sampel, dibagi menjadi 2 kelompok yaitu kelompok perlakuan dengan terapi tambahan alopurinol pada terapi standar CHF dan kelompok kontrol dengan terapi standar CHF tanpa terapi tambahan alopurinol. Hasil analisis deskriptif awal dan akhir variabel penelitian menjelaskan rerata, simpang baku, serta nilai $P$ (kemaknaan) antara kelompok allopurinol dan kelompok kontrol.

Analisis perbedaan rerata asam urat, TDS, dan TDD pre-post antara kelompok alopurinol dengan kelompok kontrol

Pada kelompok allopurinol didapatkan perbedaan rerata pre-post asam urat tidak bermakna $(P=0,076)$, perbedaan rerata prepost TDS tidak bermakna $(P=0,650)$,, dan juga perbedaan rerata pre-post TDD tidak bermakna $(P=0,356)$. Pada kelompok kontrol didapatkan perbedaan rerata prepost asam urat tidak bermakna $(P=0,322)$, perbedaan rerata pre-post TDS tidak bermakna $(P=0,065)$, dan juga perbedaan rerata pre-post TDD tidak bermakna ( $P$ $=0,157$ ) (Tabel 3, Gambar 1-3). 
Analisis perbedaan selisih rerata asam urat, TDS, dan TDD kelompok alopurinol dengan kontrol

Pada kelompok allopurinol didapatkan perbedaan selisih rerata pre-post asam urat tidak bermakna $(P=0,029)$. Perbedaan selisih rerata pre-post TDS tidak bermakna $(P=0,197)$, demikian pu;a perbedaan selisih rerata pre-post TDD tidak bermakna ( $P=0,087$ (Tabel 4).

Tabel 1. Karakteristik sampel penelitian kelompok kontrol

\begin{tabular}{|c|c|c|c|c|c|}
\hline & $\mathbf{N}$ & Minimum & Maximum & Mean & SD \\
\hline \multicolumn{6}{|c|}{ Kelompok kontrol } \\
\hline Usia & 20 & 40 & 76 & 61,25 & 8,058 \\
\hline TDS pre & 20 & 110 & 170 & 135,00 & 18,209 \\
\hline TDD pre & 20 & 70 & 110 & 83,00 & 9,234 \\
\hline AU pre & 20 & 7,00 & 14,10 & 8,3800 & 1,76802 \\
\hline AU post & 20 & 7,00 & 17,00 & 8,6850 & 2,09317 \\
\hline TDS post & 20 & 110 & 150 & 129,00 & 10,712 \\
\hline TDD post & 20 & 70 & 100 & 81,00 & 5,525 \\
\hline \multicolumn{6}{|c|}{ Kelompok perlakuan } \\
\hline Usia & 20 & 40 & 74 & 60,85 & 9,230 \\
\hline TDS pre & 20 & 90 & 190 & 126,00 & 22,100 \\
\hline TDD pre & 20 & 60 & 100 & 77,50 & 11,180 \\
\hline AU pre & 20 & 7,10 & 11,50 & 9,3500 & 1,40282 \\
\hline AU post & 20 & 3,90 & 14,90 & 8,2800 & 2,53950 \\
\hline TDS post & 20 & 90 & 160 & 124,50 & 15,035 \\
\hline TDD post & 20 & 60 & 90 & 79,50 & 6,048 \\
\hline
\end{tabular}

Tabel 2. Karakteristik sampel penelitian kelompok control

\begin{tabular}{lcc}
\hline & Kelompok alopurinol & Kelompok kontrol \\
\hline Termuda & 40 tahun & 40 tahun \\
Tertua & 74 tahun & 76 tahun \\
Rerata & 60,90 tahun & 61,25 tahun \\
$40-60$ tahun & 8 orang $(40 \%)$ & 7 orang $(35 \%)$ \\
$61-80$ tahun & 12 orang $(60 \%)$ & 13 orang $(65 \%)$ \\
\hline
\end{tabular}

Tabel 3. Perbedaan rerata pre-post asam urat, TDS, dan TDD antara kelompok allopurinol dengan kontrol

\begin{tabular}{llllllllll}
\hline & & \multicolumn{4}{c}{ Kelompok alopurinol } & \multicolumn{4}{c}{ Kelompok kontrol } \\
\cline { 3 - 9 } & & N & Rerata & Simpang Baku & P & N & Rerata & Simpang Baku & $P$ \\
\hline UA & Pre & 20 & 9,3500 & 1,40282 & $0,076^{*}$ & 20 & 8,3800 & 1,76802 & $0,322^{*}$ \\
& Post & 20 & 8,2800 & 2,53950 & & 20 & 8,6850 & 2,09317 & \\
TDS & Pre & 20 & 126,00 & 22,100 & $0,650^{* *}$ & 20 & 135,00 & 18,209 & $0,065^{* *}$ \\
& Post & 20 & 124,50 & 15,035 & & 20 & 129,00 & 10,712 & \\
TDD & Pre & 20 & 77,50 & 11,180 & $0,356^{* *}$ & 20 & 83,00 & 9,234 & $0,157^{* *}$ \\
& Post & 20 & 79,50 & 15,035 & & 20 & 81,00 & 5,525 & \\
\hline
\end{tabular}

Keterangan: * Uji T berpasangan ** uji Wilcoxon sign rank 
Tabel 4. Perbedaan selisih rerata asam urat, TDS, dan TDD antara kelompok allopurinol dengan kontrol

\begin{tabular}{llcccc}
\hline & & N & Selisih rerata & SD & P \\
\hline UA & Alopurinol & 20 & $-1,0700$ & 2,55386 & 0,029 \\
& Kontrol & 20 & 0,3050 & 1,34143 & \\
TDS & Alopurinol & 20 & $-1,50$ & 21,588 & 0,197 \\
& Kontrol & 20 & $-6,00$ & 13,917 & \\
\multirow{2}{*}{ TDD } & Alopurinol & 20 & 2,00 & 9,515 & 0,087 \\
& Kontrol & 20 & $-2,00$ & 6,156 & \\
\hline
\end{tabular}

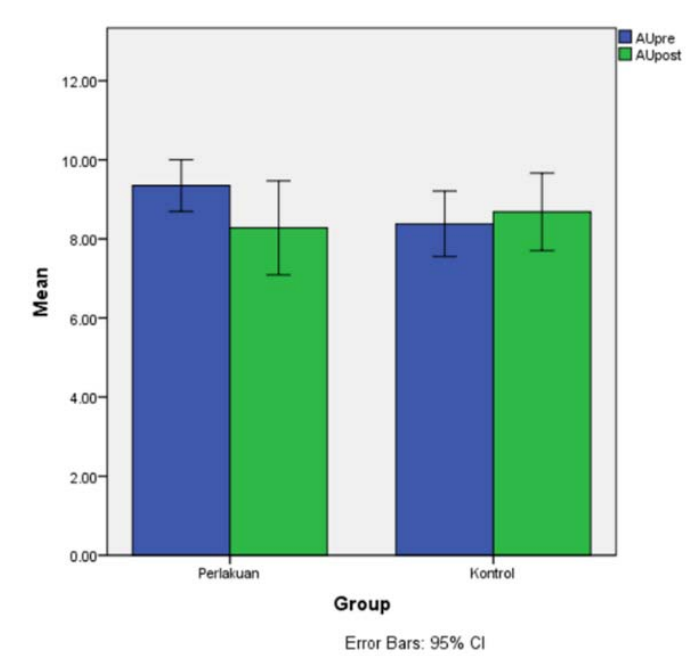

Gambar 1. Perbedaan rerata asam urat pre-post test kelompok alopurinol dengan kontrol

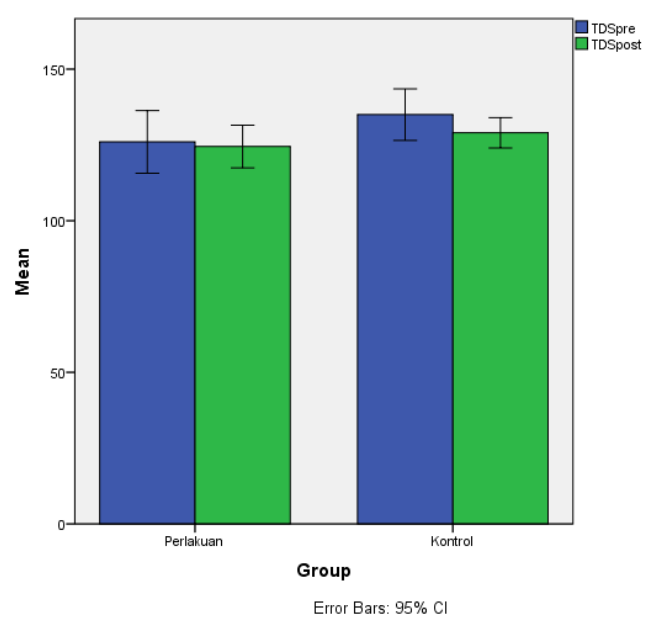

Gambar 2. Perbedaan rerata TDS pre-post test kelompok alopurinol dengan kontrol

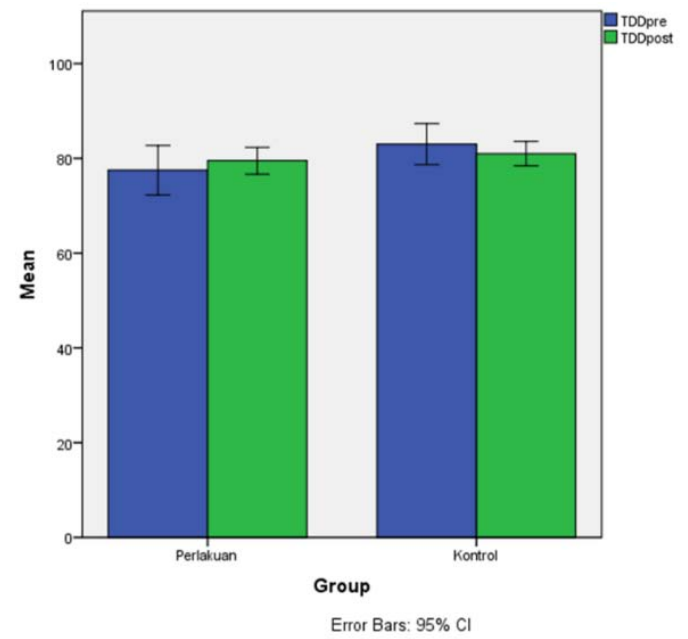

Gambar 3. Perbedaan rerata TDD pre-post test kelompok alopurinol dengan kontrol

\section{BAHASAN}

Meskipun dengan banyaknya pilihan terapi untuk hipertensi dan perubahan gaya hidup, kontrol optimal hipertensi hanya tercapai pada sekitar $40 \%$ pasien yang mengonsumsi obat antihipertensi. ${ }^{7}$ Hiperurisemia merupakan faktor independen terhadap risiko hipertensi.

Secara klinis maupun epidemiologis, asam urat serum telah diketahui memiliki hubungan, tidak hanya terhadap risiko hipertensi, tetapi juga terhadap risiko aterosklerosis, penyakit kardiovaskular dan sindroma metabolik. Asam urat memiliki peranan dalam patogenesis hipertensi dini. Pria yang menderita hiperurisemia memiliki risiko yang lebih tinggi untuk menderita hipertensi. Setiap peningkatan satu poin asam urat serum akan meningkatkan risiko sebanyak 9\% untuk menderita hipertensi. 
Walaupun mekanisme patogenesisnya belum jelas, hiperurisemia berhubungan dengan efek negatif terhadap fungsi endotel, adhesi platelet dan aggregasi, atau metabolisme oksidasi. ${ }^{2}$

Efek tingginya kadar asam urat akan berkurang pada usia lanjut, saat ketika kekakuan pembuluh darah aorta memiliki peranan penting. Usia lanjut juga dihubungkan dengan aktivasi sitem reninangiotensin dan vasokonstriksi pembuluh darah renal, sehingga hubungan keduanya menjadi tidak jelas. ${ }^{2}$ Pria memiliki risiko yang lebih besar untuk menderita hiperurisemia dibanding wanita pada setiap grup usia, walaupun perbandingan jenis kelamin akan semakin setara seiring bertambahnya usia. ${ }^{3}$ Dalam penelitian ini, diambil subjek penelitian pria berusia 40-80 tahun, yang dibagi menjadi dua kelompok. Pada kelompok perlakuan didapatkan usia termuda 40 tahun dan usia tertua 74 tahun, dengan rerata usia 60,90 tahun dan simpang baku $(\mathrm{SD})=9,107$. Pada kelompok kontrol didapatkan usia termuda 40 tahun dan usia tertua 76 tahun, dengan rerata usia 61,25 tahun dengan simpang baku $(\mathrm{SD})=8,058$. Studi oleh Lee et al. ${ }^{1}$ (Korea, 2015) mengemukakan bahwa asam urat serum dan tekanan darah memperlihatkan hubungan bermakna pada populasi umum, tetapi saat dievaluasi pada berbagai golongan usia, hanya ditemukan bermakna terhadap populasi usia $<60$ tahun.

Pada penelitian ini, dari hasil analisis statistik dengan uji Mann-Whitney U test antara tekanan darah sistolik sebelum dan sesudah 2 bulan pemberian alopurinol dalam terapi standar CHF diperoleh hubungan yang tidak bermakna $(P=0,197)$, demikian juga antara tekanan darah diastolik sebelum dan sesudah 2 bulan pemberian alopurinol dalam terapi standar CHF juga diperoleh hubungan yang tidak bermakna. Studi oleh Beattie et al. $^{4}$ (Inggris, 2014) mengemukakan hal yang sejalan, yaitu dari hasil analisis terhadap 6984 pasien tidak ditemukan hubungan antara hipertensi dengan kadar asam urat, meskipun mereka juga menemukan adanya hubungan antara asam urat dengan penurunan fungsi gunjal. Agarwal et al. ${ }^{8}$ (USA, 2012) menemukan adanya hubungan antara pemberian allopurinol dan penurunan tekanan darah walaupun hanya sedikit namun bermakna. Durasi pemberian pengobatan dan tingginya dosis alopurinol yang digunakan mungkin yang memengaruhi luaran hasil yang tidak berhubungan pada penelitian ini.

\section{SIMPULAN}

Peningkatan asam urat serum merupakan salah satu faktor risiko independen terhadap timbulnya hipertensi. Pria yang menderita hiperurisemia memiliki risiko yang lebih tinggi untuk menderita hipertensi. Penelitian ini tidak menemukan adanya hubungan bermakna antara pemberian alopurinol terhadap tekanan darah pada pasien dengan CHF.

Diperlukan penelitian yang lebih lanjut dengan skala penelitian yang lebih besar dan waktu yang lebih panjang untuk lebih mengetahui hubungan antara alopurinol dengan tekanan darah.

\section{DAFTAR PUSTAKA}

1. Lee JJ, Ahn J, Hwang J, Seong WH, Kwang NL, Kim JB, et al. Relationship between uric acid and blood pressure in different age groups. Clin Hypertens. 2015;21:14.

2. Teng F, Zhu R, Zou C, Xue Y, Yang $M$, Song $\mathbf{H}$, et al. Interaction between serum uric acid and triglycerides in relation to blood pressure. J Hum Hypertens. 2011;25(11):686-91.

3. Assob JCN, Ngowe Ngowe M, Nsagha DS, Njunda AL, Waidim Y, Lemuh DN, et al. The relationship between uric acid and hypertension in adults in Fako Division, SW Region Cameroon. J Nutr Food Sci. 2014;4:257.

4. Beattie CJ, Fulton RL, Higgins P, Padmanabhan S, McCallum L, Walters MR, et al. Allopurinol initiation and change in blood pressure in older adults with hypertension. Hypertension. 2014;64(5):1102-7.

5. James PA. Evidence-based guideline for the management of high blood pressure in adults report from the panel members appointed to the Eighth Joint National 
Committee (JNC 8). JAMA. 2014; 311(5):507-20.

6. Yamanaka $\mathbf{H}$. Essence of the revised guideline for the management of hyperuricemia and gout. JMAJ. 2012; 55(4):324-9.

7. Feig DI, Soletsky B, Johnson RJ. Effect of allopurinol on blood pressure of adolescents with newly diagnosed essential hypertension: a randomized trial. JAMA. 2008;300(8):924-32.

8. Agarwal V, Hans N, Messeril FH. Effect of allopurinol on blood pressure: a systematic review and meta-analysis. J Clin Hypertens. 2013; 15;435-42. 